\title{
Under Nutritional Interventions Using Various Snack-Base Formula of Additional Food Feeding Recovery of Spray Drying Technology
}

\author{
Arintina Rahayuni $^{1^{*}}$, Wiwik Wijaningsih ${ }^{2}$, Susi Tursilowati ${ }^{3}$ \\ ${ }^{1,2,3}$ Nutrition Department, Poltekkes Kemenkes Semarang, Indonesia
}

*Corresponding Author: Arintina Rahayuni, Nutrition Department, Poltekkes Kemenkes Semarang Indonesia, Email: rarintina@yahoo.com

\begin{abstract}
Background: Under nutrition in Central Java (2013) $17.6 \%$ is slightly lower than the national data. The efforts to overcome malnutrition and under nutrition are made by supplementary feeding recovery for 3-4 months, generally in the form of monotonous modisco that many feel bored consuming it. Modification of the menu is necessary to avoid boredom and using local materials relatively cheaper.
\end{abstract}

The Objective: This study aimed to identify the use of various snack-base formula of additional food feeding recovery of spray drying technology to increase the bodyweight of under nutrition children.

Method: The technology was used to solidify the nutrients of food by discharging the water into food powder using spray drying method, so that the calorie, protein, vitamin A, calcium, iron, zinc obtained maximum in small serving portion. The study was conducted by giving the treatment of various snacks with the addition of spray drying powder made from carrot, anchovies, and sesame $(n=20)$, as a control group comparator $(n=$ 20) given modisco. The treatments were done for four weeks. Analysis of the data treatment and control group used $\alpha=5 \%$.

Result: The results showed that the number of under-five-year who's less weight decreased from 3 respondents (treatment) and nine respondents (control). There were differences in the provision of various snacks (treatment group) and modisco (control group) to the nutritional status of weight and height of respondents. There was a trend of increasing the average of body weight of treatment group: $9.4 \mathrm{~kg}$ to 10.8 and the control group $8.9 \mathrm{~kg}$ to $9.4 \mathrm{~kg}$.

Conclusion: Giving various snacks with the added formula of spray drying is more useful to increase the body weight of under nutrition toddler. However, further research is needed with the addition of more spray drying powder on various snacks and giving the multiple snacks longer (more than four weeks).

Keywords: Under nutrition, Various snacks, Spray drying.

\section{INTRODUCTION}

The toddler is a vulnerable nutrition community for this group experiences a cycle of growth and development that require more vital nutrients than any other age group making it is easy to suffer nutritional disorders. Factors that affect the incidence of malnutrition are interrelated, namely direct factors include lack nutrition balanced in the long term and suffering from infectious diseases. While not a direct element contains the insufficient supply of food in the household, inadequate parenting, sanitation and environmental health of poor and limited access to health services ( Departement Kesehatan RI, 2009).
Efforts to overcome malnutrition and malnutrition are with supplementary feeding for 3-4 months recovery. Specifications type of food provided, among others with sufficient nutritional composition requirements minimum $1 / 3$ of 1-day needs, the energy of 350-400 calories and 10-15 gram protein. Additional food feeding recovery is generally in the form of the presentation monotonous modisco that many children get bored in taking it. Modification of menu dishes for stunting needs to be made of solid nutrition, not boring and using local materials which are relatively cheaper.

The study aims to provide interventions for stunting in the region of Demak, Central Java by giving snack foods for three months using 
the basic formula that made by a researcher with spray drying technique which is a technology tamp nutritional food by removing water on foodstuffs into powder form.

Foodstuffs have high water levels causing it to become tasteless. This formula has the advantage besides nutrient dense, due to the low water content, this recipe is more durable and more comfortable dissolved in brewed water. Besides, this powdered formula is easily applied to various forms of dishes. Therefore, to increase the acceptance of this formula product will be modified into a variety of snacks with seven variations of dishes liked by toddlers namely in the form of brownies, ice cream, cookies, meatballs, muffins, cakes, and nuggets.

\section{Materials AND MethodS}

The design used in this study is a quasiexperimental pre-post with a control group with formula administration of additional food feeding intervention and control groups of modisco. This study was conducted to determine differences in body weight and nutritional status of children before and after being treated.

The populations in this study were all stunting in the District of Guntur Demak consisting of 36 children. Toddlers were selected from 36 stunting appropriate in inclusion criteria grouped into two groups, intervention and control groups.

The univariate analysis includes: the respondent data, the nutritional value of the proximate (vitamin $\mathrm{A}, \mathrm{Fe}$ and $\mathrm{Ca}$ ), formula of additional food feeding recovery, acceptance of method other food feeding recovery and a variety of snacks, recall control and treatment groups, and also the share of consumption of the respondents consume various meal. The bivariate analysis was conducted to analyze the differences in body weight of respondents with treatment giving multiple snack formula of additional food feeding (the treatment group) and giving modisco (control group) with independent test $\mathrm{t}$-test on the degree of confidence of $95 \%$.

\section{RESULT AND DISCUSSION}

Formula powder of spray drying made from carrots, fresh wet fish, and sesame oil. In general, the process of spray drying through stages: 1) the determination of the concentration of the material to be dried, blending each ingredient with water, then measured total dissolved solids. With refractometer values obtained for carrots $=38 \%$, anchovies $=40 \%$ and sesame oil $=44 \%, 2$ ) atomization carrots, anchovies, and sesame using stirring and filtering, then the material flowed into the atomizer in the form of ring/wheel with small spinning holes. Rotations for carrots are 5000; anchovies are 6000 and sesame oil is 7000 . Droplets are formed and then dried and resized into a particle. In the atomizer, the droplet expanded surface that drying can take place more quickly, 3) droplet contact with the drying air is sprayed with high pressure on a circular nozzle (atomizer)with a temperature of $1700 \mathrm{C}$ by heating the material in $960 \mathrm{C}, 4)$ contacting the droplet with the air heat to make evaporation of water content results in droplets, so that the resulting powder and fall to the bottom of drying chamber and 5) drying the results of air separation and flaky powder in the room, air entered the separator and disposed of. Flake material is returned to the way in a blow, rejoined the line products in the process.

The process of making carrot powder of material of $10 \mathrm{~kg}$ was obtained $1234 \mathrm{~g}$ (12\%), anchovy powder $3 \mathrm{~kg}$ was obtained $992 \mathrm{~g}$ $(33 \%)$, and $1 \mathrm{~kg}$ of sesame powder obtained results of $641 \mathrm{~g}(64 \%)$. Preparation of snacks does mixing carrot powder, anchovy, and sesame as much as $40 \mathrm{~g}, 20 \mathrm{~g}$, and $40 \mathrm{~g}$. The results of laboratory analysis of the nutritional values per $100 \mathrm{~g}$ of powder mixture powder are $5.4 \mathrm{~g}$ carbohydrates, protein $43.31 \mathrm{~g}$, fat $43.85 \mathrm{~g}$, $26.16 \mathrm{mg}$ iron, calcium $1495.71 \mathrm{mg}, 0.28 \mathrm{mg}$ and vitamin zink A $2950 \mathrm{mg}$.

Flour result of spray drying is added each $50 \mathrm{~g}$ (20 g flour carrots, $20 \mathrm{~g}$ flour sesame and $10 \mathrm{~g}$ of flour anchovies) into eight kinds of snacks modifications such as biscuits, cakes, ice cream, muffins, nuggets, meatballs, brownies, and cookies, where one recipe snack produced 10 servings. The analysis showed the highest carbohydrate content in the cookies and the lowest on the ice cream as it is influenced by the water content of snacks where ice cream has a high water content but weak in cookies. The most elevated protein content is in meatballs $(17.27 \%)$, and the lowest is in the brownies (4.61\%) due to ingredients such as meat meatballs contain protein. The protein content per serving/portion for all kinds of munchies is higher than modisco protein $(3.6 \%)$ as a donation of protein snack modisco 17.73 to $66.42 \%$ and $13.85 \%$ for children $1-3$ years old 
and $13.17-49.34 \%$ and $10.29 \%$ for children $4-6$ years. The highest fat content is derived from chicken nuggets, high-fat muffin and lowest in fat than margarine in small amounts.

The calculation result of each calorie snack for muffin is $317.81 \mathrm{Kcal}$, nuggets $=494.33 \mathrm{Kcal}$, cake $=339.74 \mathrm{Kcal}$, meatball $=299.08 \mathrm{Kcal}$, cookies $=536.31 \mathrm{Kcal}$, ice cream $=410.28$ and brownies $=226.95 \mathrm{Kcal}$ Kcal. Modisco snack contributes energy 26.58 to $47.67 \%$ and $8.89 \%$ for children 1-3 years, while for children 4-6 years modisco snacks contributed 14.32 to $33.52 \%, 6.25 \%$.

The highest calcium in ice cream derived from milk materials and the lowest nuggets as chicken ingredient calcium content is not high. The content of vitamin A is almost the same for all kinds of snacks, except for slightly lower, i.e., meatballs. As for Fe, the highest and lowest brownies on ice cream as chocolate on the brownies material has a high mineral content, including $\mathrm{Fe}$, while the substance of his ice cream maker is not high in Fe. Zink at the snack almost the same, except on the highest among other snack muffin obtained from Choco chips.

The average share of consumption in the six refined formula products of spray drying is still quite low. The lowest is nuggets and ice cream was $31.56 \%$, while the highest was $39.38 \%$ brownies. The portion of refined products consumption the spray drying overall average of the six types of snack $36.38 \%$, $31.56 \%$ consume minimal pieces (nuggets and ice cream) and a maximum of $39.38 \%$ of consumption portion (brownies). Portions of each respondent's consumption of all kinds of snacks provided during four-week high on respondents both consumption almost reached $58.93 \%$, the lowest $25 \%$, and the portion modisco formula consumption on average $22.26 \%$.

Respondents in this study were divided into two groups: the treatment group was given snack formula spray drying, and the control group was given modisco every day for four weeks. Under the Nutrition Adequacy Score (NAS) children aged 1-3 years and 4-6 years of energy needs in 1125 and $1600 \mathrm{kcal}, 26$ and $35 \mathrm{~g}$ protein, Vitamin A 400 and $450 \mathrm{~kg}, 800$ and $900 \mathrm{mg}$ Calcium, Iron 6.5 and $10 \mathrm{mg}$ and Zink 5 and 11 $\mathrm{kg}$.

The recall is done against the respondent treatment, and control groups were then compared with nutritional sufficiency index for the similar age group. The result in the treatment group the number of respondents who meet the of energy, protein, vitamin $\mathrm{A}$ and $\mathrm{Fe}$ more than the control group. As for $\mathrm{Ca}$ and $\mathrm{Zn}$ both the treatment group and control NAS is insufficient.

Parents who do not work are $65 \%$ of the treatment group, and the control group is $75 \%$. Educational factors of parents, especially the mother affect the ability to receive information from the outside, especially about good parenting, how to maintain the health of their students. Mothers with a good education are considered to know the menu selection is right for their children and in determining priorities in spending.

Work status affect the socio-economic situation, which is one of the factors that determine the amount of food available in the family that helped establish the nutritional status of the family, which includes the social elements are: the state of a resident of a community, family circumstances, education level of parents and the state of the house. While the economic data of socioeconomic factors include: the work of parents, family income, family expenses, food prices are dependent on market and seasonal variation (Supariasa,2002).Many socioeconomic factors which are difficult to assess quantitatively, primarily income and property (valuables, land, cattle) because people are reluctant to talk to strangers, including the fear of taxes and robbery. Education level included in the socio-economic factors as the level of education regarding the nutritional status by increasing education will likely be able to raise revenue thus increasing the purchasing power of food to meet the nutritional needs of the family (Achadi, 2007). The lack of empowerment of the family and community resource utilization affect the family's socioeconomic factors, including the lack of empowerment of women and the level of education and knowledge of parents, especially the mother in caring for children also include social and economic factors that will affect the nutritional status of the family.

Gender of respondents in treatment group is more men $(65 \%)$, while the control group of more women $(55 \%)$. Most respondents age in the treatment group (50\%) are under the age of three years (toddlers), while the control group under the five largest (toddler) 50\%. 
Number of stunting by body weight and age in the treatment group decreased from 20 respondents into three respondents, while the control group declined from 20 respondents to 9 respondents indicating giving snack is much lower than the number of respondents giving modisco experiencing undernourishment.

Total stunting bodyweight / height in treatment group decreased from 20 respondents into five respondents, and the control group dropped from 20 respondents to 8 respondents where those who are given more nutritional snack decrease less than modisco administration. Test distinction of Mc Nemar p-value obtained bodyweight /age $=0.227$ and bodyweight / height $=0.453$, which means that $\mathrm{Ho}$ is accepted that there are differences in the provision of a variety of snack (the treatment group) and modisco (control group) on nutritional status of Weight / Age and Weight / Height of the respondents.

This is in line with Fitriyani (2012) who studied biscuits for additional food recovery where there is a significant difference before and after the administration of the nutritional status. The result proved that $100 \%$ of very thin children were reduced to $40.9 \%$ (weight/height) and $86.4 \%$ of small children were reduced to $40 \%$ (Weight / Age) with the contribution of calories $54.60 \pm 15.42 \%$ and $79.17 \pm 37.75 \%$ protein for Nutritional Sufficiency Index for children.

The results of the analysis of the condition of the initial body weight treatment and control group (independent $\mathrm{t}$-test) obtained $\mathrm{p}$-value $=$ 0.295 indicating no difference in early treatment and control groups. But, the test results of paired t-test $\mathrm{B}$ in the beginning and end of the treatment and control groups at both obtained p- value of 0.000 , proving that there is a difference of bodyweight baseline (week 0) compared to the end (week 4) in the treatment group and control group treatment where the average increase in treatment group is more substantial than the control group.

The group gave snack (treated) experienced an increase in the average of bodyweight from 9.4 $\mathrm{kg}$ to $10.8 \mathrm{~kg}$, whereas in the category of modisco administration (control) experienced an increase in the average weight of $8.9 \mathrm{~kg}$ to $9.4 \mathrm{~kg}$. In the treatment group, bodyweight tend to increase from the first week to the fourthweek snack giving.

\section{CONCLUSiON}

Providing various snacks with the added formula of spray drying is more effective to add the body weight of under nutrition toddler. But, further research is necessary with the modification of more spray drying powder on various snacks and giving the multiple snacks longer (more than four weeks) to ensure the proper portion to increase the body weight and height of under nutritional children.

\section{REFERENCES}

[1] Achadi, E (2007), Gizi dan Kesehatan Masyarakat. Jakarta : PT. Raja Gafindo Persada

[2] Departemen Kesehatan RI, 2009, Pedoman penanganan dan pelacakan balita gizi buruk. Jakarta : Departemen Kesehatan RI.

[3] Fitriyanti, F. 2012. Pengaruh pemberian makanan tambahan pemulihan terhadap status gizi balita gizi buruk di Dinas Kesehatan Kota Semarang.http//widanarta.blogspot.com/

[4] Supariasa, I.D.N., Bakri, B. \& Fajat, I., 2002. Penilaian status gizi, Jakarta: EGC.

Citation: Arintina Rahayuni, Wiwik Wijaningsih \& Susi Tursilowati. Under Nutritional Interventions Using Various Snack-Base Formula of Additional Food Feeding Recovery of Spray Drying Technology. ARC Journal of Nutrition and Growth.2018; 4(1): 10-13. DOI: dx.doi.org/ 10.20431/2455-2550.0401003.

Copyright: (c) 2018 Authors. This is an open-access article distributed under the terms of the Creative Commons Attribution License, which permits unrestricted use, distribution, and reproduction in any medium, provided the original author and source are credited. 